\title{
Media and Freedom of Expression
}

\author{
Peter Vero \\ M.Sc. Media Management, Sikkim Manipal University, India
}

\begin{abstract}
Freedom of Expression is an issue much talked about specially in conflict situations. Studies have been done on whether people can defeat the fear and regain the lost right to Freedom of expression. In the Naga case, decades of political struggle with India have made the Naga people to live under suppression from the right to freedom of expression. For many years, voices of political dissent have been silenced by the gun. People cannot voice their opinion freely for fear for their lives. A case in point in newspaper article shows a path in a different direction the society to take. All it took was for a writer who voiced his opinion by following his conscience. Is one conscience enough? Maybe to initiate, but to enjoy the right to freedom of expression, individuals and the public must raise their voice.

Keywords - Freedom of expression and Political opposition, media, opinion, views, freedom expression of idea, regulate freedom of expression; kill an idea, Naga conflict.
\end{abstract}

\section{Introduction}

"For freedom and independence, the Nagas had fought against the forced occupationists in the land of the Nagas for more than eight decades and the outfit has been conducting political dialogue with the Government of India strenuously for fifteen long years by the NSCN leadership on behalf of the Nagas to clinch an honourable settlement from India. If such an agreement takes place, certainly Nagas will get respite from tortuous struggle. But when the political dialogue seemed to reach a logical conclusion, different Naga groups and individuals have raised alarms in the name of patriotism and in the name of freedom of expression. There are so many intellectuals, philosophers and journalists who are throwing mud and dirts into the expected conclusion of the talks,". This was how the National Socialist Council of Nagalim (NSCN-IM) reacted to opinions voiced through newspapers in Nagaland. NSCN-IM said the freedom of expression can not be misinterpreted. (tntmagazine.in, Aug 25, 2012).

Freedom of expression is not unlimited. For the people whose political struggle has continued for decades in bloody war with Indian army and later in inter factional war, free expression of opinion resulted in the loss of lives. The Naga National Council (NNC), is considered by many as the sole legitimate forum to address the matter of a final solution on grounds of having initiated the plebiscite of 1951, have suffered due to the signing of the Shillong Accord of 1975 with the Government of India by some under the name of 'underground organization'. The group of Naga presidential envoy on their return from china formed the NSCN in 1980 saying 'freedom comes from the barrel of the gun' in its socialist manifesto. NSCN has since then split into three factions.

In this situation of political conflict between the Naga army, termed as rebels, undergrounds and secessionists by India and the mighty Indian army, and later further aggravated by inter factional war for territorial supremacy, political propaganda in writing kept being forced into local newspapers by the former. Media came under constant threat by these forces, which did not tolerate any opinion it considered anti-national (read anti-ideological). Intellectuals who stood for opposing principles and voiced their belief through newspapers and pamphlets were silenced by gun.

By 1997, the NSCN faction led by Th. Muivah and Isaac entered into political dialogue with the Government of India. Since then negotiation process has moved on with no transparency on the developments of the series of talks. Efforts have been made by Forum for Naga Reconciliation (FNR) which has shown a ray of hope. Killings have been reduced drastically except for sporadic incidents. However, as expectations of a negotiated settlement of the NSCN-IM-GOI talks and speculations of the shape of things to come and turn of events, opinions raised thorough the press have not been received well by the NSCN-IM. The political overtones raised caused an intimidating reaction of bygone days after relatively peaceful period. Thus, freedom of expression in this context has become a hot issue of debate.

Therefore, the term freedom of expression needs to be understood and as to how it should be limited, if it is not 'unlimited'. In the context of unresolved political dispute, the Naga political aspiration has already cost its people dearly. Where is the place for freedom of expression? Does it hold any significance in a conflict situation to learn from? Can freedom of expression play any constructive role towards the peace process? Or will the gun regulate it? In order to understand this better, some of the opinions, which are the cause for debate, shall be analysed. 


\section{Freedom of expression and media situation in Nagaland}

Expression of ideas and opinions finds medium with particular force through the channel of Press. In Nagaland, the press primarily has been and remains to be the most popular means of mass communication. By far the most popular form of communication reaching the highest number of people is the newspaper. In this sense, periodical, magazines and books have very limited readership.

The lone Radio and Television stations are Government owned and rather for news, and promotion of programmes and policies of the government. As such, expression of opinion in writing is commonly found in the four newspapers viz., Nagaland Post, Eastern Mirror, The Morung Express and Nagaland Page.

Other than the traditional media, the new media forums such as Facebook, blogs etc have found popularity among the younger generation and Internet savvy population. Expression of opinion on these mediums have been considered encouraging. However, here too, provocative expressions, communal outbursts, and the like have become a cause for alarm.

All said, freedom of expression for the Nagas reflects the kind of mental trauma they live. Charles Chasie writes thus, "Our people are going through a very trying time at this moment. The pages of our newspapers are enough to tell us that there is physical, mental and spiritual agony. There is confusion, anger, fear and suspicion everywhere. Factional fights and killings and other physical incidents continue in our towns and villages where innocent Nagas frequently become victims. Absence of clear information on the on-going NSCN-IM and GoI talks, has itself become a generator of all kinds of rumours, feeding on people's fears and suspicions, and further clouding perceptions in an atmosphere that is already murky enough. All these have created situations of heightened tension all around us." (Chasie, 2006)

\section{Freedom of expression and political opposition}

The UN Human Rights Committee notes that the Convention places a particularly high value on uninhibited debate concerning political figures and public institutions. Laws which prohibit or restrict criticism of important people and institutions are cause for concern the Committee says. "The mere fact that forms of expression are considered to be insulting to a public figure is not sufficient to justify the imposition of penalties... all public figures, including those exercising the highest political authority such as heads of state and government, are legitimately subject to criticism and political opposition". The same should apply to institutions such as the army. Committee member, Michael O'Flaherty says, "The main point of the general comment and of the Committee adopting it is that freedom of expression is at the heart of the entire human rights system." "That means," he says, "we have to put up with a lot of speech that we don't like. (UN Human Rights Committee, 2011)

Freedom of expression is considered a basic human right to be enjoyed by every member of the society. Freedom of expression is crucial to that society that is undergoing reconciliation process. For it is the cornerstone of any democratic society. Freedom of expression is often regarded as an integral concept in modern liberal democracies where it is understood to outlaw censorship. Free speech is also protected by international human rights, notably under Article 19 of the Universal Declaration of Human Rights, although implementation remains lacking in many countries. Theories with regards to freedom of expression are abounding in varied situations and contexts. Curbed or restricted freedom of expression could result from fear of government retribution as well as social pressures. Freedom of expression is integral to tolerance, and this has been a basic value in the Naga society. This right, which the people enjoyed since the days when they were headhunters, has been shaping the moral and intellectual character of the society.

In today's age of modern printing press and Internet, freedom of expression has taken the regressive direction in political context. An uneasy hope is reflected in the mood of the people as they express their opinion more openly, expecting rejoinders(read ridicule, rebuke). It is a relief though that those days of intolerance and taking lives simply owing to an individual's expression of opinion has become a bygone thing. As the negotiation between NSCN and GOI neared imminence of political settlement, opinions have been raised more freely than ever. However, the turn of events with rebuttals, rejoinders and counter-rejoinders have cast an uneasy feeling among the people. This time, the outcome has taken a new direction. More writings have come in support and against the issue concern. The outcome can be considered healthy in the sense that an organization, which feared or rather dictated, has realized its limitations and many more have participated in voicing their thoughts.

Thepfulhouvi Solo expressing utter shock at all political parties unite in the state to support Thuingaleng Muivah, the supremo of the National Socialist Council of Nagalim as they met the Indian Prime Minister. He likened them 'lock, stock \& barrel', as 'the deep seated fear of the barrel of the Gun and the Fund availability'. Solo writes that this 'indicates great political managerial skill in the young Chief Minister'. It is true that "Nagaland has always been saying: "any solution of the Indo-Naga Political Problem should be brought about by the majority consent of the Naga Groups and the Government of India has always been saying so'. Solo questioned that 'the FNR has moved heaven and earth to bring the Groups to Oneness of the Nagas. How can then the Elected Members of the Nagaland Assembly; lock, stock \& barrel, support only one Group -the 
NSCN (IM) alone? '(Solo, 2012)

The Ministry of Publicity (MIP) of the NSCN-IM countered every aspect of the opinion and goes on to conclude with "The Naga political case is not an ordinary issue, but is a very serious matter. It is a blood soaked case. So, they must be very careful in their write ups."Solo's article was enough to spark the ever relevant 'freedom of expression', which never received so much support like before.

Kekhrie Yhome in his article on the confrontation between NSCN-IM and Mr. Thepfulhouvi Solo over the latter's opinion in Nagaland news papers opines that many Nagas have shut themselves up because they are tired of bloody (in adjectives) killings in the name of the nation. Yhome observed that the digital space on Naga politics is spewed with more virulent venom by faceless bloggers, compared to a mini-thought of Mr. Solo's perhaps vast knowledge and solutions in process. He goes on to propone that "Nagas (or, whatever it may be), has come of age, and, that gun-slinging intellectualism or nationalism, has come of post-age, too, to either reconnect threat tactics as real or remain as a chimera of annoyed barking-dogs of self-appointed Naga nationalists, in indefinite ceasefire and loving it (ROFL!)! An aberration like this is shameless, petty, and cheap - but to put an icing of fear and familiar death threat warning rings a bell either of nastiness wallowing in frustration or a step beyond to accomplish such freedom fighting egoism will only serves as a prelude to an imminent coming of an idea to an end." (Yhome, 2012)

Of course, this time Thepulhouvi Solo in his reply states, "The last sentence is a veiled threat to silence Opinions other than theirs (NSCN-IM) and this undemocratic means is what the Writer does not accept. This is the whole trouble which has become of the Naga Political Case: The Naga Political Case has become a Naga Blood Soaked Case rather than a Political Case. The conversion of 'Naga Political Case' into 'Naga Blood Soaked Case' is not by the Civilians but by the Armed Naga Groups like the dreadful NSCN (IM) for one. And Solo goes on to quote a bible verse from the Bible saying "the Organization may not welcome Opinion from the Writer", which reads: Gen. 4: 9 - 10: "And the LORD said unto Cain, Where is Abel they brother? I know not: Am I my brother's keeper? And he said, What hast thou done? The voice of thy brother's blood cries out to me from the ground". Everyone has to answer for the blood he or she spilled of others. (Solo, 2012)

These writings, which seemed to have caught the attention and imagination of the elite writers, the definition of freedom of expression was loud and clear. It has sent a strong message that people wants to voice their opinions free from any fear. N Khotuo Yhome writes thus, "Long before the white men arrived, in little Naga villages, the young and the old, the rich and the poor and, the wise and the fool would sit together and discourse about the society. One by one, each will put his views across, amid laughter and debate. The white men saw and appreciated. The Indians saw and appreciated. To this very day, the tradition goes on in our villages and towns. The universal right, Freedom of Expression, does not exist in some countries, but it is our tradition from the beginning and is the foundation of our customary practices.

The case of Solo's write up and the rejoinders is unique. Unlike western thought, it is not a conflict of peoples' right to freedom of expression and authority. It is the conflict between tradition and anti-tradition. The very concept of our nationalism is born from our tradition. Destroy the tradition and the nationalism is destroyed. Solo's view need not be right or wrong. He is free to express his views according to our tradition. He does not represent any authority or the editorial. He represents himself as a conscientious citizen. If there are important matters which the laymen may not discuss, authority should maintain official secrecy or provide information on the need to know basis. That was not the case. Information published in the papers is for the people, so they have the right to agree or disagree, debate or comment. The rejoinders expose the wide gap between those who represent and those represented. How can we share our dreams if we cannot share our views? We all know that countries using repressive measures dwell in deep mistrust and hatred. The people forget the sacrifices of their leaders and preserve only the memories of their tyranny. Let us preserve our great tradition by respecting one another's views. (Yhome, 2012)

"It is a matter of appreciation that the silent majority of concerned and responsible citizens among the Nagas are beginning to make an effort to ventilate their points of view that would invariably impact our future in one form or the other. As is the way of the world, such views being expressed may find acceptability among some or rejection among others, but it does provide a healthy platform to debate and crystallize our understanding to a given subject." (Sema, 2012)

Suffice to say that in what was an expression of opinion in a newspaper came under attack by regulatory stance of an organization, the right to freedom of expression is now more liberated and made better aware to the people. Experience have shown that people have come of age and that freedom of expression can exist in conflict stricken society so long as there remain a single voice of conscience.

\section{Conclusion}

The lesson that can be learnt from this confrontation in the press is that the right to freedom of expression of the people cannot be suppressed. For the people must decide their own future. After all, the NSCN (IM) leadership itself "has said that ultimately it will be the people who decide Nagaland's future. And all shades of opinions have categorically asserted that lasting peace hinges on all warring groups speaking in one 
voice. Will the NSCN(IM) heed this? The ceasefire's objective is merely to create a congenial atmosphere for talks, reconciliation and unity - and a final settlement will follow only when the leaders change their attitude." (Lama, 2012).

Thepfulhouvi Solo admits that he was "greatly encouraged: yes, not only because they supported me but because I could see a germination of earnestness and resoluteness in the new generation to speak with conviction, reality and a nascent freedom from fear of the barrel of the gun, the nemesis of the Nagas for a long time past. This curse of the barrel of the gun on the brow of Nagas must be lifted up jointly by individuals and the nameless public for the good of all Nagas, -good and bad! .... (Solo, 2012)

Solo's experience has shown that whatsoever regulation that stands in the way of the right to freedom of expression must be lifted up jointly by individuals and the public. The case in Nagaland demonstrates an optimistic picture that may not be possible in every conflict situations. However, the Naga case has shown that an organization which wielded so much power and fear have to ultimately give way to freedom of expression. This is not to mean that the right to freedom of expression has without its limitations. In a reaction to Solo's writings, the NPF Press and Media Bureau writes thus, "We believe that an environment where citizens are allowed to express their views and opinions without any hurdle will strengthen democracy and contribute towards progress of society as a whole. The party is opposed to any section or individual who tries to suppress the voice of another person or group through undemocratic means using threat and intimidation in any manner. A civilised and progressive society must stand united in support of freedom of expression. However, in voicing opinions, it is crucial that accuracy of facts is maintained and irresponsible observations that have the potential to mislead the minds of the people are not made.” (NPF Press and Media Bureau, 2012)

\section{References}

[1] tntmagazine.in, (2012). NSCN and Freedom of Expression, (Accessed on Aug 27, 2012 )

[2] Chasie, Charles, (2006). Where are Naga People Headed?, Astha Bharati, Dialogue, Volume 7 No. 4 Freedom of expression and new media.

[3] http://www.ohchr.org/EN/NewsEvents/Pages/FreedomExpressionandnewmedia.aspx,1September2011.

(Accessed on Aug 27, 2012)

[4] Solo, Thepfulhouvi, ( 2012 ). The political acumen of the Chief Minister, www.morungexpress.com/Infocus/84383.txt. (Accessed on Aug 28, 2012)

[5] Yhome, Kekhrie, (2012). To kill an idea by killing the author. www.morungexpress.com/Perspective/84778.txt. (Accessed on Aug 30, 2012)

[6] Solo, Thepfulhouvi , (2012). Apropos Thepfulhouvi Solo's write-up and MIP IM rejoinder, The Morung Express. (Accessed on August 17, 2012)

[7] Yhome, N Khotuo, (2012). Our great tradition: Freedom of expression, Nagaland Post. (Accessed on 26 Aug. 2012)

[8] Sema, Khekiye K, (2012). Sharing A Thought, The Morung Express. (Accessed on August 24, 2012)

[9] JB Lama, (2012). So much for a truce that continues to foster disagreement, The Statesman. (Accessed on 5 August 2012)

[10] Thepfulhouvi Solo, (2012). Things that deserve appreciation, Nagaland Post. (Accessed on 24 Aug. 2012)

[11] NPF Press and Media Bureau, (2012). NPF on Solo's article, Nagaland Post. (Accessed on 19 Aug. 2012) 